\title{
ANALYSIS OF THE VEGETATION OF THE SANDSTONE RIDGES (IB LAND TYPE) OF THE NORTH-EASTERN PARTS OF THE MAPUNGUBWE National Park, Limpopo Province, South Africa
}

\author{
ALBIE R. GÖTZE \\ SAREL S. CILLIERS \\ ${ }^{1}$ School of Environmental Sciences and Development \\ North-West University \\ Potchefstroom \\ South Africa \\ HUGO BEZUIDENHOUT \\ Arid Ecosystem Research Unit \\ Conservation Services \\ South African National Parks \\ Kimberley \\ South Africa
}

KLAUS KELLNER ${ }^{1}$

Correspondence to: Sarel S. Cilliers

e-mail: sarel.cilliers@nwu.ac.za

Postal Address: School of Environmental Sciences and Development, Section Botany, Private Bag X6001, North-West University, Potchefstroom, 2531, South Africa

\begin{abstract}
The establishment of the Mapungubwe National Park has been an objective of several conservationists for many years. The ultimate objective is that this park should become a major component of a Transfrontier National Park shared by Botswana, Zimbabwe and South Africa. The aim of this study was to identify, classify and describe the plant communities present in the Ib land type of the park. Sampling was done by means of the Braun-Blanquet method. A total of 48 stratified random relevés were sampled in the Ib land type. All relevé data were imported into a TURBOVEG database, after which the numerical classification technique TWINSPAN was used as a first approximation. Subsequently, Braun-Blanquet procedures were used to refine data and a phytosociological table was constructed, using the visual editor, MEGATAB. Two plant communities and several subcommunities and variants were identified and described from the phytosociological table.
\end{abstract}

Keywords: Braun-Blanquet procedures, Mapungubwe National Park, phytosociology, savanna biome, vegetation classification

The establishment of the Mapungubwe National Park (initially the Vhembe-Dongola National Park) has been an objective of South African National Parks for many years. The main motivation has been the rich biodiversity of the area, its great scenic beauty and the cultural importance of the archaeological treasures of Mapungubwe. The artefacts discovered at this site rank among the most important pieces of ancient history yet found in sub-Saharan Africa (Willcox 1966). The significance of this proposed park and its surrounding areas is further enhanced by the potential role of the area as a sanctuary for some of the most endangered mammals on earth, such as the black rhinoceros and the African wild dog (Robinson 1996).

One of the primary goals of nature conservation should be focused on preserving diversity and the persistence of species (Walker 1989). When the natural habitats of plants have been destroyed, it is possible to cultivate and conserve plants in botanical gardens, but there is little of the genetic variation, as found between plants in their natural habitats, in botanical gardens (McNaughton 1989). Therefore, in order to conserve nature and its resources, it is important that nature reserves/national parks are upgraded and managed well (Brown 1997). Nature reserves and national parks provide reservoirs of a country's fauna and flora (Greyling \& Huntley 1984; Brown 1997). A sound knowledge of the vegetation ecology of areas of conservation significance is essential for the establishment of efficient wildlife and environmental management programmes and the compilation of conservation policies (Bredenkamp \& Theron 1978; Bredenkamp et al. 1993; Bezuidenhout 1996). Edwards (1972) stated that the optimal use of natural resources cannot be taken care of without adequate knowledge of the ecosystems involved.

In the Mapungubwe National Park, the Ib land type (Figure 1) has the second highest plant diversity of all the land types in the park, with 219 plant species identified during the course of this study. There are a large number of microhabitats within each of the larger identifiable habitats, and these contribute to the high species diversity and complex nature of the $\mathrm{Ib}$ land type. These microhabitats range from depressions in the rock surface, where soil that is transported by wind and water is trapped, to vertical face-rock habitats and cracks and seams in the mother rock. Because of the complexity of the habitats within this land type, the classification of the resulting complex vegetation was a great challenge.

The Ib land type is scattered with signs of the ancient civilisation of the world-renowned Mapungubwe Hill. The Mapungubwe Cultural Landscape is one of the UNESCO World Heritage Sites of South Africa (Huffman 2005). Rock paintings and petroglyphs, primeval building sites and age-old potsherds are commonly found in the area. This Heritage Site is an extremely important site in the early history of southern Africa, as it was here that social, cultural and political developments led to the first complex society in southern Africa (Huffman 2005, Kuman et al. 2005). Notwithstanding the unique vegetation of the 


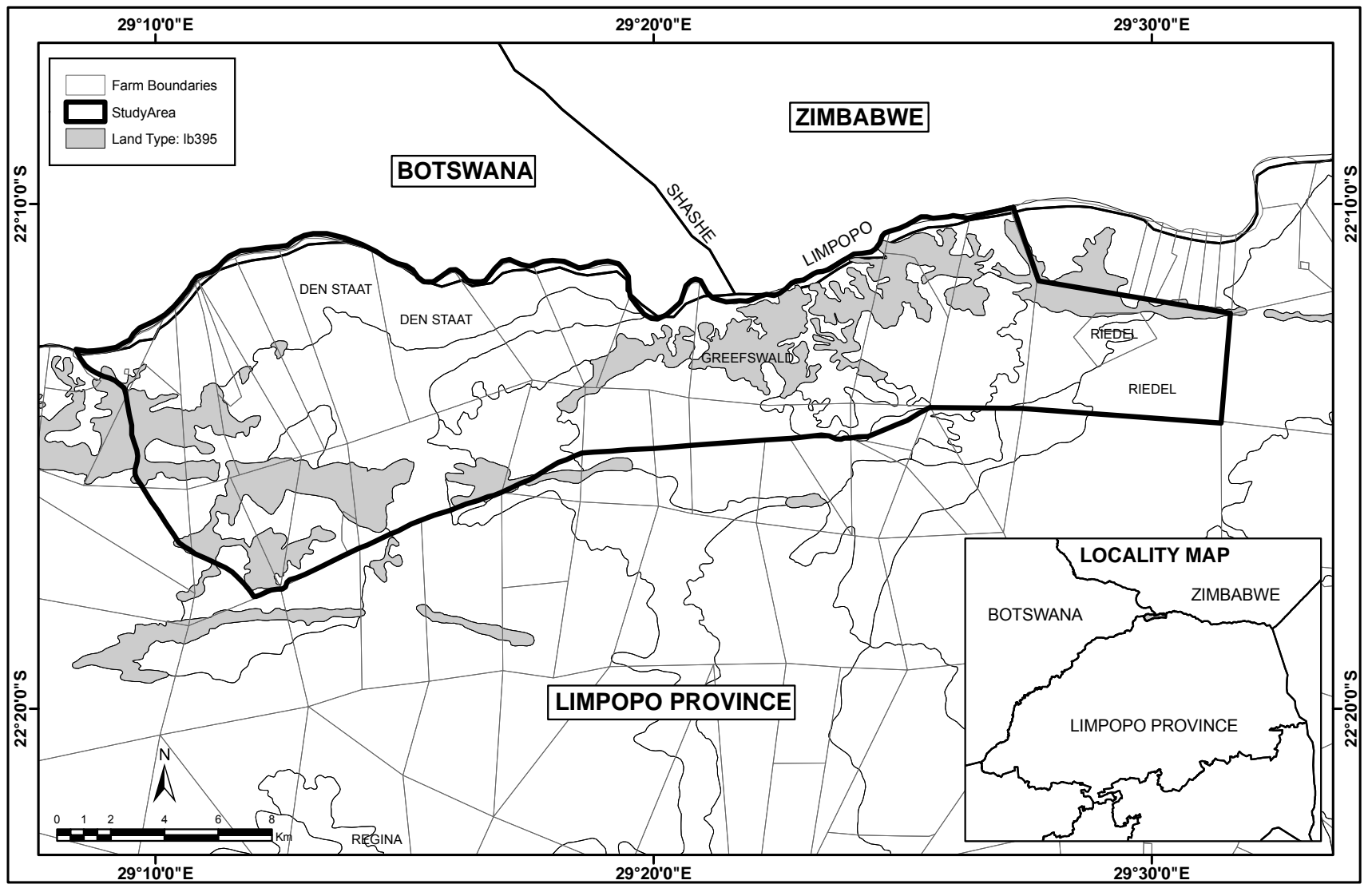

FIGURE 1

Location of the Ib land type in the Mapungubwe National Park

area, the archaeological and cultural heritage is an important reason for the proclamation of the Mapungubwe National Park (Robinson 1996).

The aims of this study were to identify, classify and describe the plant communities of the study area based on plant species composition, environmental variables and anthropogenic influences. Information generated by this study could be further used in conjunction with vegetation studies on all the other land types in the Mapungubwe National Park (Götze 2002; Götze et al. 2003) to identify and map ecologically sound management units on which the optimal management of the park could be based, including recommendations on restoration practices for degraded areas (Götze 2002).

\section{STUDY AREA}

The Mapungubwe National Park is centred on the confluence of the Limpopo and Shashi Rivers in the Limpopo Valley in the Limpopo Province of South Africa. It lies on the international borders between Botswana, Zimbabwe and South Africa (Robinson 1996) (Figure 1). Sandstone ridges were studied on the farms Greefswald and Riedel, because entrance was restricted to the other farms (Figure 1), as they were not formally included in the park at the time the survey was done (Götze 2002).

The climate is semi-arid, with a long-term mean annual rainfall of $350 \mathrm{~mm}$ per annum (Willcox 1966; Robinson 1996). Rainfall is highly variable and usually falls during the summer months between October and March. Surface drainage is mostly in a northerly direction towards the Limpopo River. None of the rivers in the area, including the Limpopo, are perennial. The study area is between $300 \mathrm{~m}$ and $780 \mathrm{~m}$ above sea level. South of the Limpopo River the topography tends to be flat with sandstone and conglomerate ridges and koppies. Nearer the Limpopo River the plains give way to a rugged, hilly terrain.
According to Van Rooyen and Bredenkamp (1996), the study area is situated in Mopane Bushveld, while Acocks (1988) placed it in veld type no.15, also called Mopane Veld. The most recent vegetation map of South Africa, Lesotho and Swaziland (VEGMAP) places the Ib land type in the Limpopo Ridge Bushveld in the Mopane Bioregion of the Savanna biome (Mucina et al. 2005, Mucina \& Rutherford 2006). Other vegetation studies done in the Mapungubwe National Park and the surrounding areas include a terrain and vegetation evaluation by the former South African Defence Force (South African Defence Force 1986a, 1986b), a study by O'Connor (1991) of vegetation types in the Limpopo-Venetia Nature Reserve, and a vegetation survey by Timberlake et al. (1999) of the Maramani/Tuli Area, across the Limpopo River in south-western Zimbabwe. Other studies in the Musina area that included parts of the Limpopo Ridge Bushveld were done at the Messina Experimental Farm (Dekker \& Van Rooyen 1995) and the Honnet Nature Reserve (Visser et al. 1996). However, none of the previous studies focused specifically on the sandstone ridges of the Ib land type.

Robinson(1996) stated that the park hasnumerous archaeological sites dating from the Early Stone Age to the present. Many of these sites, which are concentrated in the area of the confluence of the Limpopo and Shashi Rivers, are of major importance and scientific value. Of particular interest is the Zhizo site (AD 700-900) on the farm Schroda, and Mapungubwe Hill and the adjoining Bambandyanalo (AD 1100-1250), situated on the farm Greefswald. According to Voigt and Plug (1981), the Mapungubwe site is considered to be of major importance in sub-Saharan Africa and is the most remarkable Iron Age site in South Africa. Additional features of importance are the numerous rock paintings and petroglyphs found in the area.

\section{METHODS}

With the aid of different maps of the area, such as topographical, geological, soil and existing vegetation maps and aerial 
photographs, a preliminary evaluation of the study area was made. In conjunction with this, a detailed reconnaissance of the area was done to determine homogeneous areas in the vegetation before sampling commenced. Using visual estimates, sampling was done by means of the Braun-Blanquet method (MuellerDombois \& Ellenberg 1974). Land types were used to stratify the study area. Other land types that were studied included the Ia (Götze et al. 2003), Db, Fb and Ae land types (Götze 2002). A total of 48 stratified random relevés, each covering an area of $50 \times 50 \mathrm{~m}$, were sampled.

Plant nomenclature follows Germishuizen et al. (2006) and soil classification was done in accordance with the Soil Classification Work Group (1991). Trees and shrubs were classified using the guidelines set by Edwards (1983). Trees were classified as rooted, woody, self-supporting plants over $2 \mathrm{~m}$ high and with one or a few definite trunks, and shrubs were classified as rooted, woody, self-supporting, multi-stemmed or singlestemmed plants less than $2 \mathrm{~m}$ in height (Edwards 1983).

The habitat conditions, including geology, soil forms and other edaphic factors, slope, aspect and the rockiness of the soil surface were qualitatively described for each relevé. This information was used in the description of the different plant communities. The coordinates of each relevé were determined with the use of a GPS and noted.

All relevé data were imported into the TURBOVEG database (Hennekens 1996a). The numerical classification technique TWINSPAN (Hill 1979a), which is regarded by several phytosociologists (Mucina \& Van Der Maarel 1989; Bredenkamp \& Bezuidenhout 1995; Cilliers 1998) as a successful approach for classification, was used as a first approximation to classify the floristic data. Subsequently, Braun-Blanquet procedures (Bezuidenhout et al. 1996) were used to refine data and construct phytosociological tables (Table 1) using a visual editor, MEGATAB (Hennekens 1996b). Using the phytosociological tables and the habitat information gathered during the sampling period, the different plant communities were identified and described.

\section{RESULTS AND DISCUSSION}

\section{Classification}

The Ib395 land type (Figure 1) contains a unique habitat that consists of rocky koppies with shallow lithosols of the Mispah and Glenrosa soil forms. The terrain occupied by this land type is made up of rugged crest areas (Terrain Unit $1=\mathrm{TU} 1$ ), vertical cliffs (TU2), foot slopes (TU3) and drainage areas at the very foot of the sandstone koppies (TU5). The geology is made up of sandstone and siltstone of the Clarens Formation of the Karoo Sequence (Land Type Survey Staff 2000).

The following vegetation types were identified:

1. The Hexalobus monopetalus - Croton gratissimus var. subgratissimus community

1.1 The Psydrax livida - Oropetium capense subcommunity

1.1.1 The Mundulea sericea - Zornia glochidiata variant

1.1.2 The Strychnos madagascariensis - Coleochloa pallidior variant

1.2 The Ficus tettensis - Waltheria indica subcommunity

1.2.1 The Stipagrostis uniplumis - Pavonia dentata variant

1.2.2 The Hibiscus coddii - Tragia rupestris variant

2. The Terminalia prunioides - Grewia bicolor community 2.1 The Acacia senegal - Barleria senensis subcommunity

2.2 The Colophospermum mopane - Vernonia cinerascens subcommunity

2.3 The Hermbstaedtia odorata - Heliotropium ovalifolium subcommunity
Description of the plant communities

1. The Hexalobus monopetalus - Croton gratissimus var. subgratissimus community

The Hexalobus monopetalus - Croton gratissimus var. subgratissimus community has a high plant species diversity, with more than 152 species recorded during this study. The community consists of a complex mosaic of microhabitats on rocky outcrops in shallow sandy Mispah and Glenrosa soil forms. This community is found mainly on the farm Greefswald in the Mapungubwe National Park.

Large areas of bare sandstone are common and constitute between 30 and $70 \%$ of the total surface area. The community is moderately grazed, mostly by small wildlife types. This is due to the fact that the largest part of this rocky community is inaccessible to most large mammals. The community is home to a healthy population of the nimble klipspringer (Oreotragus oreotragus), which feeds on herbs and shrubs on or at the base of rocky outcrops (Wynne-Jones 1982). Apart from natural weathering of sandstone and natural erosion of the resulting sand particles, no other erosion of a serious nature was observed in the area.

The diagnostic plant species of the Hexalobus monopetalus - Croton gratissimus var. subgratissimus community are found in species group A (Table 1). These include the tree species Hexalobus monopetalus var. monopetalus, Croton gratissimus var. subgratissimus, Ficus abutilifolia and Philenoptera violacea, and the shrub species Abutilon grandiflorum and Ochna inermis. The diagnostic grasses are a Trichoneura sp., Schmidtia pappophoroides, Aristida scabrivalvis subsp. scabrivalvis and Brachiaria nigropedata, and the other herbaceous species include the sedge species Bulbostylis hispidula subsp. pyriformis and the forbs Evolvulus alsinoides, Cleome hirta and Barleria affinis (species group H, Table 1). This community is further differentiated from the Terminalia prunioides - Grewia bicolor community (2) by the absence of the species of species group I (Table 1).

The average tree height of this community is $3.3 \mathrm{~m}$ and the canopy cover varies from 10 to $50 \%$. The shrub layer has an average height of $1.3 \mathrm{~m}$ and a canopy cover of between 6 and $60 \%$. The herbaceous layer varies in canopy cover from 30 to $71 \%$, with an average height of $0.5 \mathrm{~m}$.

Two subcommunities and four variants were identified in this community. The subcommunities are as follows:

1.1 The Psydrax livida - Oropetium capense subcommunity

1.2 The Ficus tettensis - Waltheria indica subcommunity

1.1 The Psydrax livida - Oropetium capense subcommunity This subcommunity is found almost exclusively on the Mispah soil form and, in a few cases, on the Glenrosa soil form, mostly on the crest (TU1) and to a lesser extent on cliff sides (TU2) and foot slopes (TU3) of the Ib land type. Shallow soils with a soil depth of up to $20 \mathrm{~cm}$ are found in depressions in the rock surface. Herbaceous species and small shrubs are found in these depression microhabitats. Deeper soils occur in run-off areas, crevices and seams in the rock, where a larger amount of soil has accumulated with a soil depth of up to $50 \mathrm{~cm}$, which is more suitable for plant growth. Grazing in the area is concentrated in the run-off areas, which are more accessible to game. It was also observed that these latter areas are utilised by wildlife for shelter.

A common microhabitat occurring in this subcommunity is small depressions in the mother rock, which are filled by windand water-transported soil and in which small herbaceous species have become established. The grass species Oropetium capense (species group B, Table 1) and the sedge Bulbostylis hispidula subsp. pyriformis (species group A, Table 1), together with some other small herbs and grasses, occur in these depressions. 
TABLE 1

Phytosociological table of the vegetation of the IB land type in the north-eastern parts of the Mapungubwe National Park

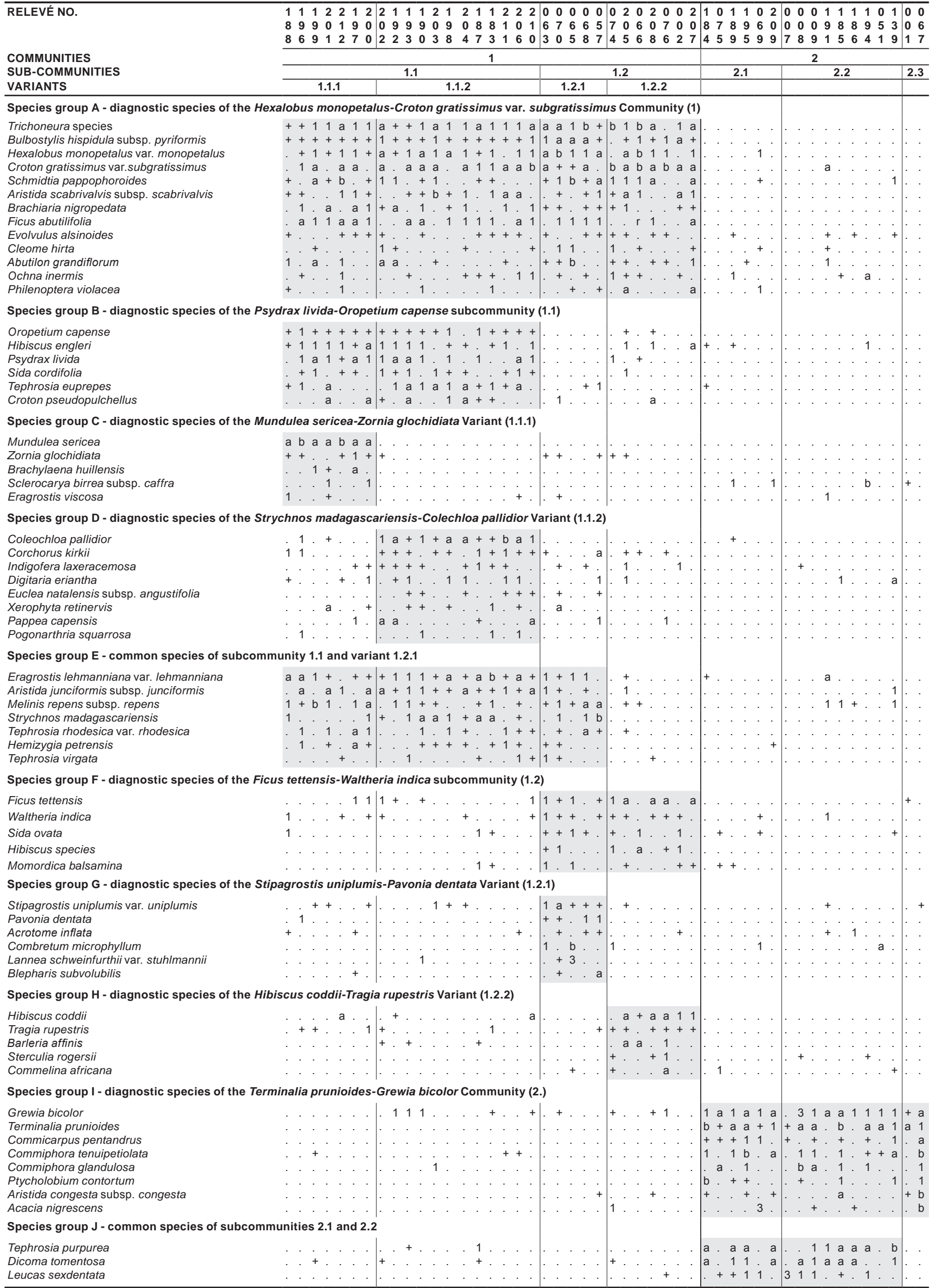


TABLE 1 (CONT...)

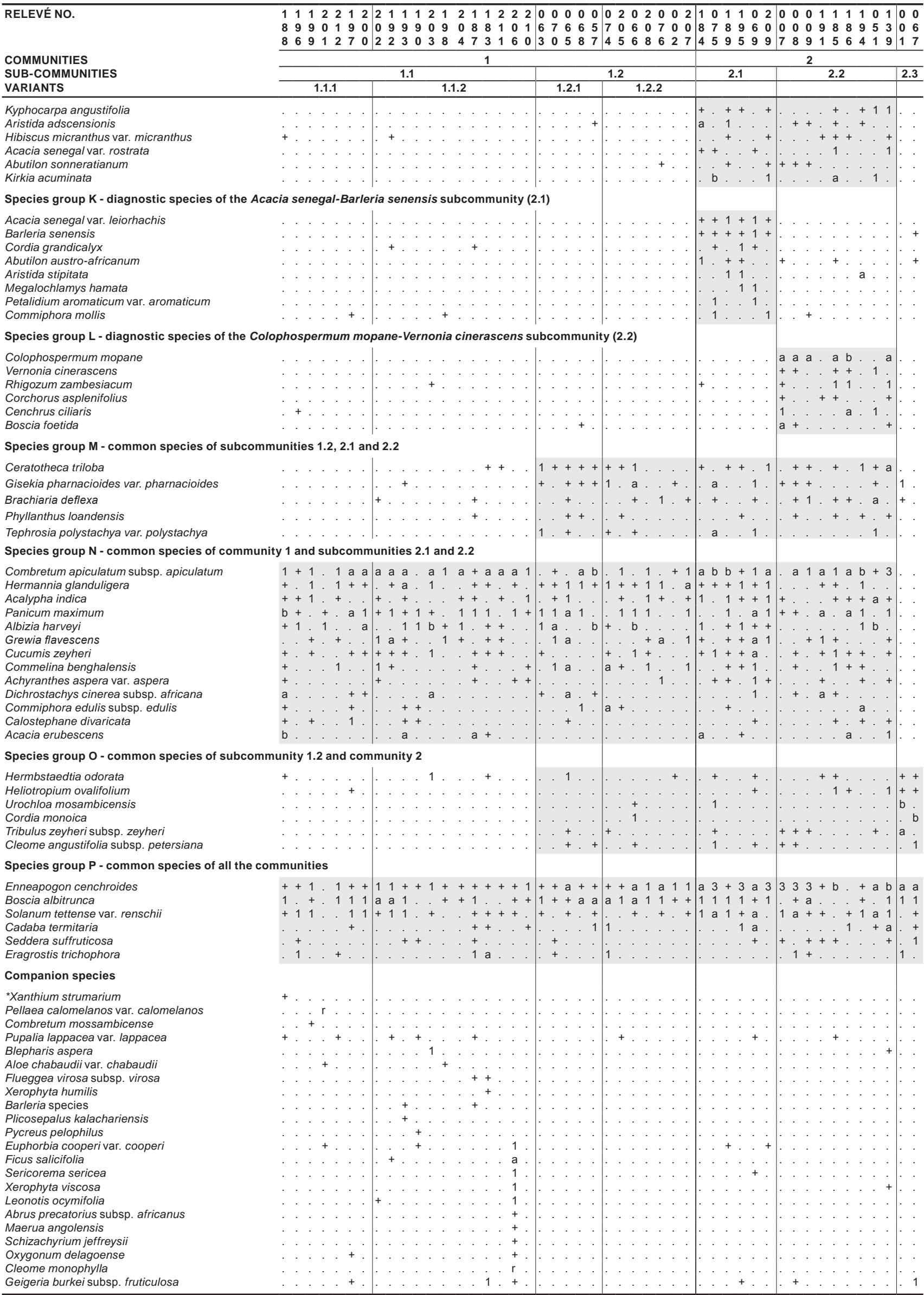




\begin{tabular}{|c|c|c|c|c|c|c|c|c|c|c|c|c|c|c|c|c|c|}
\hline RELEVÉ NO. & $\begin{array}{l}1 \\
8 \\
8\end{array}$ & & & & & & & & & & & & & & & & 00 \\
\hline COMMUNITIES & & & & & & & & & & & & 1 & & & & & \\
\hline SUB-COMMUNITIES & & & & & & & 1.1 .150 & & & & & & & & & & \\
\hline VARIANTS & & & 1.1.1 & & & & & & & 1.1 & & & & & & & \\
\hline $\begin{array}{l}\text { Merremia pinnata } \\
\text { Vigna species }\end{array}$ & + & & . . & . & . & . . & . & & . & . & + & . & + & . & . & . &. \\
\hline Vigna frutescens subsp. frutescens & + & & . . & . & . & . & . & & . & . & . & . & . & . &. & & .1 \\
\hline Sesamum triphyllum var. triphyllum & . & . & . & . & . & . & $r$ & & & . & . & . & . & . & . & . & . \\
\hline Cyperus rupestris var. rupestris & . & & . . & . & . & . & . & & . & . & . . & . . & . & . & . & . & + . \\
\hline Marsdenia sylvestris & . & & & . & & & . & & & & . & . . & . & . & & & + . \\
\hline Indigofera charlieriana var. charlieriana & . &. & . . & . & & & r. & & . & . & . & . & . & $r^{\prime}$ & . & $\mathrm{r}$ & + . \\
\hline Vangueria infausta subsp. Infausta & . & & . . & . & & & . & & + & & . . & + & & 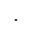 & . & . & . . \\
\hline Cassia abbreviata subsp. beareana & . & & & . & & & . & & & & . & + . & . & . & . & $\cdot$ & . . \\
\hline Monechma divaricatum & . & & . . & . & & . & r. & . & . & . & . . & . . & . & . & . & . & . . \\
\hline Panicum schinzii & . & & . . & . & & . & . & & . & & . . & . . & . & . &. & . & . . \\
\hline Bridelia mollis & . & . & . . & . & . & . . & . & . & . & . & . . & . . & . & . & . & . & . . \\
\hline Steganotaenia araliacea var. araliacea & . & & . . & . & & . . & . & . & . & . & . . & . & . & . & . & [0 & . . \\
\hline Ctenolepis cerasiformis & . & & & . & & & . & & & & . & . . & . & . & . & . & . . \\
\hline Monsonia senegalensis & . & & . . & . & & & r. & & . & . & . & + & . & $r^{\prime}$ & . & . & . . \\
\hline Nemesia fruticans & . & & . . & . & & . . & . & & . & . & . . & - . & . & . & . & . & . . \\
\hline Ocimum americanum var. americanum & . & & . . & . & & & . & & . & . & . . & - . & . & . & . & . & . . \\
\hline Kohautia aspera & . & & . . & . & & & . & & . & . & . . & . . & . & . & . & . & . . \\
\hline Hermannia modesta & . & & . . & . & & . & . & & . & . & . . & . . & . & . &. & . & . . \\
\hline Grewia tenax var. tenax & . & . & . . & . & . & . . & . & . & . & . & . & . . & . & . & . & . & . . \\
\hline Hibiscus sabiensis & . & & . . & . & & & . & & . & . & . . & . . & & . & . & . & . . \\
\hline Melhania rehmannii & . & & . . & . & & & . & & . & & . & . . & . & . & . & . & . . \\
\hline Setaria sagittifolia & . & & . . & . & & & . & & . & & . . & & . & . &. & . & . . \\
\hline Panicum deustum & . & & . . & . & & . & . & & . & . & & & . & . & . & . & . . \\
\hline Justicia protracta subsp. rhodesiana & . & & . . & . & & & . & & . & . & . . & . . & . & . & . & . & . . \\
\hline Decorsea schlechteri & . & & . . & . & & & . & & . & . & . . & . . & . & . & . & 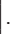 & . . \\
\hline Asparagus africanus & . & + & . . & . & & & . & & . & . & . . & . . & . & . &. & . & . . \\
\hline Grewia occidentalis var. occidentalis & . & . & . . & . & . & . & . & . & . & . & . . & - . & & . & . & . & . \\
\hline Ipomoea sinensis subsp. blepharosepala & . & $\cdot$ & . . & . & & . & . & . & . & & . . & . & . & . & . & . & . . \\
\hline Acacia mellifera subsp. detinens & . & & . . & . & & & . & & . & . & . . & . . & . & & . & . & . . \\
\hline Loudetia simplex & . & . & . . & . & . & . . & . & . & . & . & . . & . . & . & . & . & . & . . \\
\hline Commiphora viminea & ${ }^{\circ}$ & & . . & . & & & . & & . & . & . & & . & . & . & 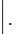 & . \\
\hline Euphorbia species & . & & . . & . & & & . & & . & & . . & . . & . & . & . & . & . . \\
\hline Neuracanthus africanus & . & . & . . & . & & . . & . & . & . & . & . . & . . & . & . &. & 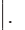 & . . \\
\hline Tinnea rhodesiana & . & . & . . & . & & 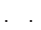 & 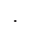 & . & . & . & . . & . . & . & . &. & . & . . \\
\hline Chamaecrista absus & . & & . . & . & & . & . & . & . & . & . . & . . & . & . & . & . & . . \\
\hline Adansonia digitata & . & . &. & . & & . & . & . & . & . & . & . . & . & . & . & . & . . \\
\hline Vahlia capensis subsp. vc & . & & & . & & & . & & . & & & & . & & & 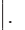 & . . \\
\hline Acacia tortilis subsp. heteracantha & . & . & . . & . & . & . & . & . & . & . & . . & . . & . & . & . & . & . . \\
\hline Cucumis metuliferus & . & & . & . & & + & & & . & & 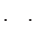 & . & . & . & . & . & . \\
\hline Crotalaria species & . & & . . & . & & . & . & & . & & . . & . . & . & . & . & . & . . \\
\hline${ }^{*}$ Bidens pilosa & . & . & . . & . & & . & . & . & . & . & . . & . . & . & . & . & 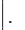 & . . \\
\hline Indigofera heterotricha & . & . & . . & . & . & 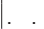 & 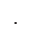 & 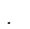 & . & & . & . . & . & . & . & . & . . \\
\hline Pavonia burchellii & . & & . . & . & & . & . & & . & & . . & . . & . & . & . & & . . \\
\hline Grewia villosa & . & &. & . & & . & . & . & . & . & . & . . & . & & . & . & . . \\
\hline Euphorbia eylesii & & & . . & . & & & & & & & & & . & + & & & . . \\
\hline Crotalaria virgulata subsp. grantiana & . & . & . . & . & & & . & . & . & . & . . & . . & . & . & . & . & . . \\
\hline Indigofera trita subsp. subulata & . & & . & . & & + & & & . & & & . & . & & . & & . \\
\hline Merremia kentrocaulos & . & & . . & . & & . & . & & . & & . . & . . & . & & . & . & . . \\
\hline Ximenia americana var. microphylla & . & . & . . & . & & . & . & & . & . & . . & . . & . & . & . & . & . . \\
\hline Ipomoea magnusiana & . & & 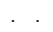 & + & & . & 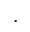 & . & . & & . . & . . & . & . & . & . & + . \\
\hline Melhania acuminata var. agnosta & + & & . . & . & & . & . & & . & & & + & . & . & 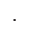 & & + . \\
\hline Dichilus lebeckioides & + & . & . . & . & . & . & . & . & . & & . . & . & . & & . & . & \\
\hline Monsonia glauca & 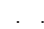 & & . & . & & & . & & . & & . & + & . & & & & . . \\
\hline Asparagus suaveolens & . & & . . & . & & . & & . & . & & . . & & . & . & & & . . \\
\hline Balanites pedicellaris subsp. pedicellaris & . & & . & . & & . & . & & . & & & & . & 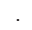 & & & . \\
\hline Asparagus laricinus & 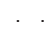 & & . . & & & . & . & & . & & . & & . & & . & . & \\
\hline Barleria transvaalens & . & . & . . & . & & . & . & 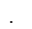 & . & . & . . & . . & . & . & . & . & . . \\
\hline Berchemia zeyheri & . & . & . & & & . & . & . & . & & . & . . & . & & & . & \\
\hline Cadaba aphylla & . & & & . & & & & & . & & & & . & . & & & . . \\
\hline Aristida rhiniochloa & . & & . . & . & & . . & . & . & . & & . & & . & . & . & & . \\
\hline Becium filamentosum & & & & . & & & & & & & & & 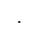 & & & & . \\
\hline Bothriochloa insculpta & . & & . & . & & & & . & . & & . & . . & . & . & . & & . . \\
\hline *Plumbago zeylanica & & & . & . & & & & & . & & & & . & & & & \\
\hline Aptosimum lineare var. lineare & + & & . & . & & & . & & . & & ${ }^{\circ}$ & . & . & . & & & . \\
\hline Amaranthus species & . & & . & . & & & . & & . & . & . & . & . & . & & & . . \\
\hline *Alternanthera pungens & . & . & . & . & & . & . & & . & & & . & . & . & & & . . \\
\hline${ }^{*}$ Chenopodium carinatum & & & & . & & & & & & & & & . & & & & \\
\hline Chloris virgata & . & . & . & . & & . . & . & . & . & . & . & & . & & . & & . \\
\hline Dactyloctenium aegyptium & & & . & . & & & & & . & & & & & & & & \\
\hline Eleusine coracana subsp. africa & & & & - & & & & & & & & & . & & & & \\
\hline Indigastrum costatum subsp. macrum & . & & . & 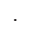 & & 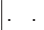 & . & & . & . & & . & 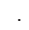 & & & & \\
\hline *Schkuhria pinnata & & & & . & & & & & & & & & . & & & & \\
\hline Setaria verticillata & & & . . & . & & & . & & . & & 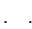 & & 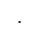 & & & & 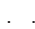 \\
\hline Tragus berteronianus & . & & & . & & 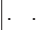 & & & . & & & & . & . & & & + . \\
\hline Enneapogon desvauxii & & & & & & & & & & & & & & & & & \\
\hline Indigofera circinnata & & & & . & & & & & & & & & & & . & & \\
\hline Indigofera species & & & & & & & & & & & & & & & & & \\
\hline
\end{tabular}

* exotic species 
The diagnostic species of this subcommunity are found in species group B (Table 1) and include the tree species Psydrax livida and the shrubs Croton pseudopulchellus and Hibiscus engleri. The diagnostic species also include the grass species Oropetium capense and the forbs Sida cordifolia and Tephrosia euprepes. This subcommunity is differentiated from the Ficus tettensis - Waltheria indica subcommunity (1.2) by the absence or infrequent occurrence of the species of species groups $\mathrm{F}$ and M (Table 1)

The tree species cover between 10 and $35 \%$ of the area, and have an average height of $3.0 \mathrm{~m}$. The shrub layer has an average height of $1.3 \mathrm{~m}$ and the canopy cover varies between 6 and $26 \%$. The average height of the herbaceous layer is $0.5 \mathrm{~m}$ and the canopy cover varies between 30 and $60 \%$ of the subcommunity area.

Two variants were identified in the Psydrax livida - Oropetium capense subcommunity:

1.1.1 The Mundulea sericea - Zornia glochidiata variant

1.1.2 The Strychnos madagascariensis - Coleochloa pallidior variant

1.1.1 The Mundulea sericea - Zornia glochidiata variant This variant is most commonly found on crests (TU1) and less commonly on foot slopes (TU3) in the Psydrax livida - Oropetium capense subcommunity (1.1). The dominant soil form is Mispah, while Glenrosa occurs to a lesser extent. The soils are shallow and sandy in texture. Approximately $35 \%$ of the area is overlain by solid sandstone and the rockiness of the available soil surfaces is between 55 and 70\%. This variant shows signs of moderate grazing because it is accessible to larger mammals in some instances. This variant occasionally was observed in the vicinity of natural seeps and rock pools filled with water during the rainy period.

The diagnostic species of the Mundulea sericea-Zornia glochidiata variant are found in species group C (Table 1). These include the tree species Mundulea sericea, Brachylaena huillensis and Sclerocarya birrea subsp. caffra, the grass species Eragrostis viscosa and the forb Zornia glochidiata. This variant is differentiated from the Strychnos madagascariensis - Coleochloa pallidior variant (1.1.2) by the infrequent occurrence or absence of the species of species group D (Table 1). Large specimens of the tree species Ficus abutilifolia are also common in this variant.

The average height of the tree layer is $3.0 \mathrm{~m}$ and the canopy cover ranges from 10 to $35 \%$. The shrub layer has an average height of $1.3 \mathrm{~m}$ and canopy cover varying between 10 and $25 \%$. The herbaceous layer covers between 40 and $60 \%$ with an average height of $0.5 \mathrm{~m}$.

1.1.2 The Strychnos madagascariensis - Coleochloa pallidior variant This variant makes up approximately $60 \%$ of the surface area of the Psydrax livida - Oropetium capense subcommunity (1.1). It occurs mainly on the undulating foot slopes (TU3) of the $\mathrm{Ib}$ land type, but also to a lesser extent on the crests of the terrain (TU1). The main soil forms are sandy Mispah and Glenrosa soils. Grazing levels seemed to be lower than in the Mundulea sericea - Zornia glochidiata variant (1.1.1), as this area is less accessible to large mammals. The plant diversity of this variant is marginally higher than that of the Mundulea sericea - Zornia glochidiata variant (1.1.1), probably due to the larger number of microhabitats found in this variant because of the more undulating nature of the terrain, which provides more microclimates than the open, flat terrain of the Mundulea sericea - Zornia glochidiata variant (1.1.1). It was noted that most of the larger tree species were found growing in seams and crevices in the sandstone. The rockiness of the soil surface varies between 50 and $75 \%$ and roughly $30 \%$ of the area consists of bare rock.

Diagnostic species include the tree species Euclea natalensis subsp. angustifolia, which also occurs in shrub form, and Pappea capensis, the grasses Digitaria eriantha and Pogonarthria squarrosa, the sedge Coleochloa pallidior and the forbs Corchorus kirkii, Indigofera laxeracemosa and Xerophyta retinervis (species group D, Table 1). Species with high cover abundance values are the tree species Strychnos madagascariensis (species group E, Table 1) and the shrubs Croton pseudopulchellus (species group B, Table 1) and Grewia flavescens (species group N, Table 1).

The tree layer has an average height of $3.0 \mathrm{~m}$ and a canopy cover varying between 10 and $35 \%$. The shrub layer covers between 6 and $26 \%$ of the variant area, with an average height of $1.2 \mathrm{~m}$. The herbaceous layer reaches an average height of $0.5 \mathrm{~m}$ and the canopy cover varies between 30 and $60 \%$.

1.2 The Ficus tettensis - Waltheria indica subcommunity

This subcommunity of the Hexalobus monopetalus - Croton gratissimus var. subgratissimus community (1) occurs on deeper Glenrosa and Mispah soil forms than the Psydrax livida Oropetium capense subcommunity (1.1). This subcommunity is situated on crests (TU1), steep cliff sides (TU2) and to a certain extent on the upper parts of the foot slopes (TU3) of the Ib land type. The so-called cliff sides on these sandstone ridges seldom have a vertical drop. The drop usually forms small, sometimes narrow terraces. On the ledges formed by the terrace-like terrain, shallow to moderately deep soils have accumulated and serve as a growth medium for tree species (especially the wild fig species such as Ficus abutilifolia, F. tettensis and F. salicifolia).

The diagnostic species of this subcommunity are found in species group F (Table 1). They include the tree species Ficus tettensis and the forb species Waltheria indica and Sida ovata, Hibiscus species and the climber Momordica balsamina. The absence or infrequent occurrence of species group B (Table 1), along with higher cover abundance values for the sedge species Bulbostylis hispidula subsp. pyriformis (species group A, Table 1), differentiates this subcommunity from the Psydrax livida - Oropetium capense subcommunity (1.1). The presence of the species of species group $M$ (Table 1) further differentiates this subcommunity from the other subcommunity (1.1) of the Hexalobus monopetalus - Croton gratissimus var. subgratissimus community (1).

The tree layer has an average height of $3.8 \mathrm{~m}$. This is on average $80 \mathrm{~cm}$ higher than the tree layer of the Ficus tettensis - Waltheria indica subcommunity. The tree cover of this subcommunity varies between 5 and $50 \%$. The shrub layer reaches an average height of $1.5 \mathrm{~m}$ and has a varying canopy cover of 22 to $60 \%$. The herbaceous layer covers between 35 and $70 \%$ of the area and has an average height of $0.6 \mathrm{~m}$

Two variants were identified in this subcommunity:

1.2.1 The Stipagrostis uniplumis - Pavonia dentata variant

1.2.2 The Hibiscus coddii - Tragia rupestris variant

1.2.1 The Stipagrostis uniplumis - Pavonia dentata variant This variant is most commonly situated on the crest (TU1) and foot slope (TU3) of the Ib land type. The Glenrosa soil form dominates the area occupied by the variant and the Mispah soil form occurs less regularly. The areas in which this variant is found have deeper soils than those of the Hibiscus coddii - Tragia rupestris variant (1.2.2). The variant is minimally grazed and no severe signs of vegetation and soil degradation were observed. Large portions of bare rock surfaces are present and cover approximately $35 \%$ of the area. The rockiness of the soil surface is between 30 and $40 \%$.

The diagnostic species of the Stipagrostis uniplumis - Pavonia dentata variant are found in species group G (Table 1). They include the tree species Lannea schweinfurthii var. stuhlmannii, the woody creeper Combretum microphyllum, the grass Stipagrostis uniplumis and the forbs Pavonia dentata, Acrotome inflata and Blepharis subvolubilis var. subvolubilis. Pavonia dentata is regarded as an endemic species to the Limpopo Ridge Bushveld (Mucina 
\& Rutherford 2006). Other species that differentiate this variant are the shrub Dichrostachys cinerea (species group N, Table 1) and the forb Ceratotheca triloba (species group M, Table 1). The presence of the species of species group E (Table 1) further differentiates this variant from the Hibiscus coddii - Tragia rupestris variant (1.2.2)

The tree layer is well developed, with an average height of $4.0 \mathrm{~m}$ and a canopy cover of 15 to $50 \%$. The shrub layer has a canopy cover ranging from 22 to $60 \%$ and an average height of $1.5 \mathrm{~m}$. The herbaceous layer covers 35 to $71 \%$ of the area and reaches an average height of $0.6 \mathrm{~m}$.

\subsubsection{The Hibiscus coddii - Tragia rupestris variant}

This variant is found on moderately deep and shallow soils on the crests (TU1) and cliff sides (TU2) of the Ib land type. The main soil forms are Glenrosa and Mispah. The variant is often found on the verges of cliff sides and also on ledges and crevices on steep inclines of the sandstone ridges. Grazing levels are low and the area as a whole is not seriously degraded. Open rock surfaces cover about 40 to $50 \%$ of the area of the variant and the rockiness of the soil surface is between 20 and 30\%.

Diagnostic species of this variant are found in species group $\mathrm{H}$ (Table 1) and include the tree species Sterculia rogersii, the shrubby Hibiscus coddii and the forbs Tragia rupestris and Commelina africana. The absence of the shrub Dichrostachys cinerea (species group N, Table 1), as well as the species of species groups $E$ and $G$ (Table 1) further differentiate this variant from the Stipagrostis uniplumis - Pavonia dentata variant (1.2.1).

The tree layer has a canopy cover varying between 5 and 30\%, with an average height of $3.5 \mathrm{~m}$. The shrub layer reaches an average height of $1.3 \mathrm{~m}$ and has a canopy cover varying from 5 to $50 \%$. The canopy cover of the herbaceous layer varies from 20 to $66 \%$, with an average height of $0.5 \mathrm{~m}$.

2. The Terminalia prunioides - Grewia bicolor community

This community is found on shallow and moderately deep soils on the crests (TU1) and foot slopes (TU3) of the Ib land type and occurs on the two farms Greefswald and Riedel in the Mapungubwe National Park. The common soil forms found in this community are shallow Mispah and deeper Glenrosa lithosols, as well as moderately deep Hutton soils. The soils generally have a sandy texture and, as a result, are well drained. The largest portion of this community is underlain by sandstone as the mother rock, and a smaller portion is underlain by intrusions of dolerite. These dolerite areas are in the form of long, narrow intrusions, often cropping out in jagged hilly formations or rocky flats. Approximately 10 to $30 \%$ of the area of the community is covered by exposed bedrock and between 20 and $50 \%$ of the available soil surface is covered by rocks. The area is moderately grazed and, in some places, is trampled by game. With the exception of the Hermbstaedtia odorata - Heliotropium ovalifolium subcommunity, the Terminalia prunioides - Grewia bicolor community is generally in a good condition.

The diagnostic species of this community are found in species group I (Table 1). These species include the tree species Terminalia prunioides, Commiphora tenuipetiolata, C. glandulosa and Grewia bicolor, with the latter occurring mostly in shrub form. Other diagnostic species are the grass species Aristida congesta subsp. congesta and the bushy forb Commicarpus pentandrus. The Terminalia prunioides - Grewia bicolor community (2) is differentiated from the Hexalobus monopetalus - Croton gratissimus var. subgratissimus community (1) through the absence or infrequent occurrence of the species of species group A (Table 1). These two communities only have a few species in common, namely the general species of species group P (Table 1).
The tree layer of this community has a canopy cover of between 10 and $57 \%$ and an average height of $4.8 \mathrm{~m}$. The shrub layer covers between 5 and $45 \%$ of the area, with an average height of $1.4 \mathrm{~m}$, and the herbaceous layer has a varying canopy cover of 32 to $90 \%$ and an average height of $0.5 \mathrm{~m}$.

Three subcommunities were identified in the Terminalia prunioides - Grewia bicolor community (2), namely:

2.1 The Acacia senegal - Barleria senensis subcommunity

2.2 The Colophospermum mopane - Vernonia cinerascens subcommunity

2.3 The Hermbstaedtia odorata - Heliotropium ovalifolium subcommunity

2.1 The Acacia senegal - Barleria senensis subcommunity

This subcommunity is found on dolomite outcrops and on areas with a mixture of sandstone and dolomite on the crests (TU1) and foot slopes (TU3) of the Ib land type on the farm Greefswald in the Mapungubwe National Park. The soil forms that dominate this variant are Glenrosa and Mispah. The soils are shallow and have a sandy to loamy texture. Approximately $30 \%$ of the surface area of the variant is covered by solid rock and the rockiness of the soil surface is between 30 and $45 \%$. The area is moderately grazed and animals utilise bush clumps for shelter.

Diagnostic species are found in species group K (Table 1) and include the woody species Acacia senegal var. leiorachis, Commiphora mollis and Cordia grandicalyx, with the latter often occurring in shrub form. The diagnostic species further include the shrubby Abutilon austro-africanum, the grass species Aristida stipitata and the forbs Barleria senensis, Megalochlamys hamata and Petalidium aromaticum var. aromaticum. Other species that differentiate this variant from the Colophospermum mopane Vernonia cinerascens subcommunity (2.2) and the Hermbstaedtia odorata - Heliotropium ovalifolium subcommunity (2.3) are the tree species Albizia harveyi and the forbs Hermannia glanduligera (species group $\mathrm{N}$, Table 1) and to a lesser extent Tephrosia polystachya var. polystachya (species group M, Table 1).

The height of the tree layer of the Acacia senegal - Barleria senensis subcommunity averages $4.4 \mathrm{~m}$, with a canopy cover of 30 to $57 \%$. The shrub layer has an average height of $1.3 \mathrm{~m}$ and the canopy cover varies between 8 and $45 \%$. The herbaceous layer has a canopy cover ranging from 48 to $90 \%$ and an average height of $0.5 \mathrm{~m}$.

\subsection{The Colophospermum mopane - Vernonia cinerascens subcommunity}

This subcommunity is found on the farms Greefswald and Riedel in the Mapungubwe National Park. As in the case of the Acacia senegal - Barleria senensis subcommunity (2.1), it occurs on the crests (TU1) and foot slopes (TU3) of the Ib395 land type. The main soil forms found in this variant are shallow Mispah and moderately deep Glenrosa and Hutton soils. The soil has a sandy to loamy texture and in the case of Hutton soils the subsoil is rocky. The rockiness of the soil surface is between 20 and $50 \%$ and approximately 10 to $20 \%$ of the area is covered by exposed bedrock. Grazing levels are moderate to low, depending on the accessibility of the landscape.

The diagnostic species of this subcommunity are found in species group L (Table 1). They include the tree species Colophospermum mopane and Boscia foetida, the shrub species Rhigozum zambesiacum, the grass Cenchrus ciliaris and the forbs Vernonia cinerascens and Corchorus asplenifolius. Similarities between the Colophospermum mopane - Vernonia cinerascens subcommunity (2.2) and the Acacia senegal - Barleria senensis subcommunity (2.1) come in the form of the species of species group J (Table 1).

The tree layer has an average height of $4.2 \mathrm{~m}$ and a canopy cover varying between 10 and $45 \%$. The shrub layer has a canopy 
cover ranging from 5 to $40 \%$ and an average height of $1.4 \mathrm{~m}$. The canopy cover of the herbaceous layer varies between 45 and $68 \%$, with an average canopy height of $0.6 \mathrm{~m}$.

\subsection{The Hermbstaedtia odorata - Heliotropium ovalifolium} subcommunity

This highly disturbed subcommunity occurs mainly on the farm Greefswald in the Mapungubwe National Park. The degradation was caused primarily by the actions of the former South African Defence Force. The subcommunity is commonly found on old campsites, which vary from permanent to temporary camps. A large degree of deforestation and landscaping has taken place in most of these areas. It was also observed that specimens of the majestic Adansonia digitata, which were removed from the surrounding areas, were transplanted in some of these areas. As a whole, these areas are degraded severely, with large areas devoid of vegetation. An old dumping site and a case of serious soil pollution at a former fuelling station were recorded as being among the most severely degraded sites in the area.

The main soil forms vary from shallow Mispah to moderately deep Glenrosa and even some patches of Witbank soils of varying depths. The Witbank soil form comprises soils deposited by humans, usually for landfills or other landscaping works (Soil Classification Work Group 1991). The rockiness of the soil surface varies from 15 to $25 \%$. Grazing levels are moderate, but the impact of the grazing in these areas is severe due to the large degree of anthropogenic-induced degradation.

No diagnostic species were identified in this degraded subcommunity, but it was characterised by the constant occurrence and high abundance of the species of species group O (Table 1), including the shrubby Cordia monoica, the grass species Urochloa mosambicensis and the forbs Hermbstaedtia odorata, Heliotropium ovalifolium, Tribulus zeyheri subsp. zeyheri and Cleome angustifolia subsp. petersiana. This subcommunity is differentiated from the Acacia senegal - Barleria senensis subcommunity (2.1) and the Colophospermum mopane - Vernonia cinerascens subcommunity (2.2) by the absence or infrequent occurrence of the species of species groups $\mathrm{J}$ to $\mathrm{N}$ (Table 1). The poor conditions of the veld are confirmed further by the presence of the weed species Amaranthus, Alternanthera pungens, Chenopodium carinatum and Schkuhria pinnata, and the grass species Tragus berteronianus (other species, Table 1).

The tree layer reaches an average height of $6.0 \mathrm{~m}$ and a canopy cover of between 12 and $45 \%$. The shrub layer has an average height of $1.6 \mathrm{~m}$ and the canopy cover varies between 1 and $30 \%$ while the herbaceous layer reaches an average height of only $0.3 \mathrm{~m}$ and a poor canopy cover of between 30 and $45 \%$.

\section{CONCLUSION}

The high plant diversity, the great scenic beauty and uniqueness of the landscape, the cultural importance of the archaeological treasures of the Mapungubwe Cultural Landscape in the Ib land type in the Mapungubwe National Park, and a rich population of mammals, birds and reptiles, give this area a large claim to conservation.

Some of the vegetation types described in the $\mathrm{Ib}$ land type are similar to those previously described in other studies. The South African Defence Force (1986b) previously described the vegetation and habitat of the sandstone ridges of the Ib395 land type in a report on the vegetation of the maps of the areas Mapungubwe (2229AB) and Coila (2229AD). The mixed Colophospermum mopane, Combretum apiculatum, Commiphora spp. and Terminalia prunioides community identified by the South African Defence Force (1986b) was described on the same sandstone ridges of the study area in which the Hexalobus monopetalus - Croton gratissimus var. subgratissimus (1) and Terminalia prunioides - Grewia bicolor (2) communities were identified. According to the South African Defence Force (1986b), a feature of the landscape in which these communities are found is the steep irregular slopes, the shallow lithosols and the large number of large rocks (up to $30 \mathrm{~cm}$ in diameter) found on the soil surface. The Ficus tettensis - Aristida meriodinalis tall closed woodland described by Dekker \& Van Rooyen (1995) shows some similarities with the Ficus tettensis - Waltheria indica subcommunity of the Hexalobus monopetalus - Croton gratissimus var. subgratissimus community, but was associated with domeshaped granite hills in that study.

The Albizia - Combretaceae open woodland/shrubland was identified and described in a study conducted by Timberlake et al. (1999) across the Limpopo River in the south-western parts of Zimbabwe. Regarding habitat and floristic composition, this vegetation unit shows similarities with the Hexalobus monopetalus - Croton gratissimus var. subgratissimus (1) and Terminalia prunioides - Grewia bicolor (2) communities, which were identified on the Ib395 land type during the course of this study.

This study made an important contribution to our knowledge of the vegetation on sandstone hills in the Limpopo Ridge bushveld, because little was known about them previously. Due to the fragmentary nature of the Ib land type, a vegetation map was not produced. A vegetation map of the Mapungubwe National Park will be compiled after a synthesis of the current study and studies on other land types, such as the Ia land type (Götze et al. 2003) and the $\mathrm{Db}, \mathrm{Fb}$ and Ae land types (Götze 2002, Götze et al. in prep.). The synthesis will also put the communities described in this study into context with other communities in the park (interpretation of relationships between different communities), making it possible to compare the major vegetation groups and subgroups in the park with previously described units such as the different types of Mopane veld (Siebert et al. 2003). The major vegetation groups and subgroups of the Mapungubwe National Park will be used as a basis to compile and map management units (Götze 2002, Götze et al. in prep.).

\section{ACKNOWLEDGEMENTS}

South African National Parks and the Peace Parks Foundation are thanked for technical and financial assistance, and the South African Defence Force for providing soil and vegetation maps of the area. This study forms part of an MSc thesis completed at the Potchefstroom University for Christian Higher Education (now Potchefstroom Campus of North-West University).

\section{REFERENCES}

Acocks, J.P.H. 1988. Veld types of South Africa, 3rd ed. Memoirs of the Botanical Survey of South Africa 57: 1-146.

Bezuidenhout, H. 1996. The major vegetation communities of the Augrabies Falls National Park, Northern Cape. 1. The southern section. Koedoe, 39(2): 7-24.

Bezuidenhout, H., Biggs, H.C. \& Bredenkamp, G.J. 1996. A process supported by the utility BBPC for analyzing BraunBlanquet data on a personal computer. Koedoe, 39(1): 107112.

Bredenkamp, G.J. \& Bezuidenhout, H. 1995. A proposed procedure for the analysis of large data sets in the classification of South African Grasslands. Koedoe, 38(1): 33-39.

Bredenkamp, G.J. \& Theron, G.K. 1978. A synecological account of the Suikerbosrand Nature Reserve 1. The phytosociology of the Witwatersrand geological system. Bothalia, 12: 513529.

Bredenkamp, G.J., Deutschländer, M.S. \& Theron, G.K. 1993. A phytosociological analysis of the Albizio harveyi - Eucleetum divinorum from sodic bottom land clay soils of the Manyeleti Game Reserve, Gazankulu, South Africa. South African Journal of Botany, 59(1): 57-64 
Brown, L.R. 1997. A plant ecological study and wildlife management plan of the Borakalo Nature Reserve, NorthWest Province. PhD dissertation, University of Pretoria, Pretoria.

Cilliers, S.S. 1998. Phytosociological studies of urban open spaces in Potchefstroom, North West Province, South Africa. PhD dissertation, Potchefstroom University for CHE, Potchefstroom

Dekker, B. \& Van Rooyen, N. 1995. The physical environment and plant communities of the Messina Experimental Farm. South African Journal of Botany, 61(3): 158-167.

Edwards, D. 1972. Botanical survey and agriculture. Proceedings of the Grassland Society of South Africa, 7: 15-19.

Edwards, D. 1983. A broad-scale structural classification of vegetation for practical purposes. Bothalia, 14(3/4): 705-712.

Germishuizen, G., Meyer, N.L., Steenkamp, Y. \& Keith, M. (eds.). 2006. A checklist of South African plants. South African Botanical Diversity Network Report No. 41. Pretoria: SABONET.

Götze, A.R. 2002. The classification of plant communities and the evaluation of restoration technologies in different land-use areas in the Vhembe-Dongola National Park, Northern Province, South Africa. MSc thesis. Potchefstroom University for C.H.E., Potchefstroom.

Götze, A.R., Cilliers, S.S., Bezuidenhout, H. \& Kellner, K. 2003. Analysis of the riparian vegetation (Ia land type) of the proposed Vhembe-Dongola National Park, Limpopo Province, South Africa. Koedoe, 46(2): 45-64.

Götze, A.R., Cilliers, S.S., Bezuidenhout, H. \& Kellner, K. In prep. Vegetation analysis of the $\mathrm{Db}, \mathrm{Fb}$ and Ae land types of selected areas of the Mapungubwe National Park, Limpopo Province, South Africa.

Greyling, T. \& Huntley, B.J. 1984. Directory of Southern African conservation areas. South African National Scientific Programmes Report, 98: 1-310.

Hennekens, S.M. 1996a. TURBOVEG: software package for input, processing and presentation of phytosociological data. University of Lancaster: IBN-DLO.

Hennekens, S.M. 1996b. MEGATAB: a visual editor for phytosociological tables. Ulft: Giesen \& Gertus.

Hill, M.O. 1979a. TWINSPAN: a Fortran program for arranging multivariate data in an ordered two-way table by classification of individuals and attributes. Cornell University, Ithaca, New York.

Huffman, T.N. 2005. Mapungubwe, ancient African civilisation on the Limpopo. Johannesburg: Wits University Press.

Kuman, K., Le Baron, J.C. \& Gibbon R.J. 2005. Earlier stone age archaeology of the Vhembe-Dongola National Park (South Africa) and vicinity. Quaternary International, 129: 23-32.

Land Type Survey Staff, 2000. Information on the land types of the map 2228-Alldays. Pretoria: Directorate of Agricultural Information.

McNaughton, S.J. 1989. Ecosystems and conservation in the twenty-first century. In: Western, D. \& Pearl, M.C. (eds.). Conservation for the twenty-first century. Oxford: Oxford University Press. pp. 109-120
Mucina, L. \& Rutherford, M.C. (eds.). 2006. The vegetation of South Africa, Lesotho and Swaziland. Strelitzia 19. Pretoria: South African National Biodiversity Institute.

Mucina, L. \& Van Der Maarel, E. 1989. Twenty years of numerical syntaxonomy. Vegetatio, 81: 1-15.

Mucina, L., Rutherford, M.C. \& Powrie, L.W. (eds.). 2005. Vegetation map of South Africa, Lesotho and Swaziland, 1:1000 000 scale sheet maps. Pretoria: South African National Biodiversity Institute.

Mueller-Dombois, D. \& Ellenberg, H. 1974. Aims and methods of vegetation ecology. New York: Wiley.

O'Connor, T.G. 1991. The vegetation types of the LimpopoVenetia Nature Reserve. Internal Report, De Beers Consolidated Mines, Pretoria.

Robinson, G.A. 1996. Limpopo Valley National Park: towards trans-frontier conservation in South Africa. Unpublished report, South African National Parks.

Siebert, F., Bredenkamp, G.J. \& Siebert, S.J. 2003. A comparison of Mopaneveld vegetation in South Africa, Namibia and Zimbabwe. Bothalia, 33(1): 121-134.

Soil Classification Work Group, 1991. Grondklassifikasie: 'n Taksonomiese Sisteem vir Suid-Afrika. Memoirs on the Natural Agricultural Resources of South Africa 15. Pretoria: Department of Agricultural Development.

South African Defence Force. 1986a. Report on the vegetation of the map areas 2229AA, Pontdrif and 2229AC, Evangelina. Unpublished report, South African Defence Force.

South African Defence Force. 1986b. Report on the vegetation of the map areas 2229AB, Mapungubwe and 2229AD, Coila. Unpublished report, South African Defence Force.

Timberlake, J., Mapaure, I. \& Chapano, C. 1999. Vegetation survey of parts of the southern lowveld, Zimbabwe. Consultancy Report for CESVI Lowveld Project. Occasional Paper in Biodiversity No. 6. Biodiversity Foundation for Africa, Bulawayo.

Van Rooyen, N. \& Bredenkamp, G.J. 1996. Mopane Bushveld. In: Low, A.B. \& Rebelo, A.G. (eds.). Vegetation of South Africa, Lesotho and Swaziland. Pretoria: Department of Environmental Affairs and Tourism. pp. 20-21

Visser, N., Van Hoven, W. \& Theron, G.K. 1996. The vegetation and identification of management units of the Honnet Nature Reserve, Northern Province, South Africa. Koedoe, 39(1): 25-42.

Voigt, E.A. \& Plug, I. 1981. Early Iron-Age herders of the Limpopo Valley. Internal report, Transvaal Museum, Pretoria.

Walker, B.H. 1989. Diversity and stability in ecosystem conservation. In: Warren, A. \& Goldsmith, F.B. (eds.). Conservation for the twenty-first century. New York: John Wiley. pp. 121-130.

Willcox, A.R. 1966. Memorandum concerning a suggested nature reserve and archaeological reserve in the Limpopo Valley. Unpublished Memo, National Parks Board.

Wynne-Jones, A. 1982. Hunting, on safari in East and Southern Africa. Johannesburg: Macmillan. 